\title{
PSYCHOLOGICZNE ASPEKTY PROBLEMATYKI WIEKU EMERYTALNEGO STARSZYCH KAPŁANÓW
}

Przedmiotem * zainteresowania psychologii jest ogół procesów psychicznych człowieka, warunki ich powstawania, przebieg i następstwa ${ }^{1}$. Wiele przyczyn złożyło się na to, że psychologowie początkowo zwracali swoją uwagę szczególnie na dwie pierwsze fazy rozwojowe, tj. dzieciństwo i wiek dojrzewania. Psychologia wieku dorosłego przez długi czas leżała odlogiem. Toteż, nie tylko z racji logicznego i czasowego (rozwojowego) następstwa, ale i dla dalszego zainteresowania się psychologii wiekiem dorosłym, przyjęło się umownie nazywać go „trzecim wiekiem” ? Na takie stanowisko uczonych wpłynęła niewątpliwie również opinia, że w młodości kończą się definitywnie podstawowe procesy rozwojowe człowieka, a te są dla psychologów najbardziej interesujące. Ponadto dzieci i młodzież zawsze bardziej wymagały pomocy ze strony psychologa aniżeli człowiek dorosły.

Po osiągnięciu dojrzałości społecznej człowiek dorosły jest odpowiedzialny nie tylko za swoje obowiązki względem grupy społecznej, rodzinnej, zawodowej, narodowościowej czy religijnej, lecz jest on także odpowiedzialny - i to przede wszystkim — za siebie samego, za kierunek i stopień rozwoju swojej osobowości. Na ogół, każdy dorosły, w mniejszym lub w większym stopniu, radzi sobie $z$ tą odpowiedzialnością. Nie obywa się to bez wysiłku, bez chwil wątpliwości, bez błędów. Wszak człowiekiem dorosłym jest się też w życiu ,po raz pierwszy”...

Zadanie, które człowiek ma do spełnienia po raz pierwszy, zawsze stanowi trudność. Toteż, coraz częściej zdrowi dorośli korzystają z porady u psychologa, z jego fachowych uwag i wskazówek w sensie szeroko pojętej profilaktyki. Pełna sprawność umysłowa i fizyczna człowieka dorosłego pozwala mu w większości przypadków radzić sobie samemu.

* Niniejszy artykuł stanowi część obszernego studium, którego tytuł brzmi: Proces adaptacji do przejścia na emeryturę u starszych kapłanów, Kraków 1983, 250.

1 Por. T. N ow a cki, Zarys psychologii, Warszawa 1977, 7.

2 Por. W. Szewczuk, Psychologia człowieka dorosłego, Warszawa 1961, 22. 
Wskazówki psychologa są mu jednak w wielu przypadkach znakomitą pomocą.

Co innego, gdy chodzi o człowieka dorosłego w wieku starczym. W tym okresie życia staje się on znowu trochę mniej zaradnym, bardziej ostrożnym, lękliwym, podatnym na infekcje i choroby, a przede wszystkim bardzo potrzebującym odpowiedniej atmosfery uczuciowej ze strony najbliższego otoczenia. Toteż, zorganizowanie odpowiednich warunków życia starszemu człowiekowi ma zawsze ogromne znaczenie dla jego dobrego samopoczucia i pogodnego przeżywania emerytury. Nic dziwnego, że współczesna psychologia pragnie swym naukowym ramieniem wesprzeć starszego człowieka jeszcze przed jego emeryturą, a zwłaszcza, gdy na emeryturze napotka on jakieś szczególne trudności adaptacyjne.

\section{PROBLEM PSYCHOFIZJOLOGII STARZENIA SIE}

Proces starzenia się rozpoczyna się na wiele lat przed wejściem w wiek emerytalny, bo jeszcze w początkach wieku dorosłego. Stąd mówi się, że człowiek dłużej się starzeje aniżeli dojrzewa, albowiem swoją psychofizjologiczną dojrzałość osiąga człowiek między 15 a 25 rokiem swojego życia ${ }^{3}$. Natomiast, dorosłość i starość obejmują aż trzy czwarte ludzkiego życia. Jeżeli się ponadto uwzględni niektóre objawy starzenia się, stwierdzalne już po $30 \mathrm{r}$. $\dot{z} .{ }^{4}$, to można zaryzykować twierdzenie, że po bardzo krótkim dzieciństwie, po wieku dorastania i młodości, niewiele dłuższym niż dzieciństwo, człowiek się potem nieustannie już tylko starzeje, przede wszystkim, gdy chodzi o jego organizm. Następnie, we właściwym wymiarze, dotyczy to również jego funkcji organicznych i psychicznych.

Zjawisko starzenia się - jak słusznie to określa D. B. Bromley ,jest zespołem zmian zachodzących: 1) w strukturze i funkcjonowaniu organizmu oraz 2) w przystosowaniu się jednostki" 5 .

Organiczne zmiany $\mathrm{w}$ czlowieku, powstałe w wyniku procesów starzenia się, obejmują zarówno jego sferę biologiczną i jej zróżnicowaną strukturę, jak i sferę fizjologiczną (tj. funkcjonowanie organizmu). Obie te sfery są fundamentem dla funkcji psychicznych człowieka. Zdrowie i świeżość tych pierwszych decyduje o sprawności drugich.

Wypada zatem pokrótce zaznajomić się z najważniejszymi zmianami

3 D. B. Bromley, Psychologia starzenia się, Warszawa 1969, 36.

${ }^{4}$ Tenże, 62; chodzi tutaj np. o zmniejszającą się wydolność mięśni serca oddychania itp.

5 Tenże, 36. 
biologiczno-fizjologicznymi $w$ ramach procesu starzenia się ze względu na psychologiczne skutki, jakie one za sobą pociągają.

Samo starzenie się nie jest - jak to stwierdza dzisiejsza psychologia - chorobą, lecz jedynie normalnym wyczerpywaniem się organizmu u każdego człowieka. W tym miejscu należy podkreślić, że organizmy ani jako całość, ani jako poszczególne ich części, nie wyczerpują się u ludzi w jednakowym tempie ${ }^{\circ}$. Spotykane w starszym wieku choroby jak zauważa Bromley - „są to zjawiska patologiczne, odmienne od normalnych procesów starzenia się i zmian psychicznych, chociaż są z nimi związane i nakładają się na nie" ". Starzenie się więc byłoby poniekąd pewną kumulacją skutków przebytych w życiu chorób czy uszkodzeń ciała w połączeniu $\mathrm{z}$ fizjologicznymi procesami, zachodzącymi aktualnie.

Właściwy pogląd na związek starości z chorobą ukazał K. W. Schaie mówiąc, że „pewna patologia towarzyszy starości, ale nie jest przyczyną starości" 8 .

Edward Massaro (The University of Texas Center) na ten sam temat tak się wyraża: „Mimo, że fatalne skutki choroby wraz z wiekiem się potęgują, to jednak opinię, że starzenie się jest wynikiem choroby, trudno już dzisiaj podtrzymywać. Starzenie się jest skutkiem postępujących zmlan $w$ organizmie, objawiających się fizjologicznym zanikiem oraz słabnącą zdolnością do przeciwstawiania się organizmu różnym fizjologicznym niedomaganiom, tj. chorobom" '.

Pamiętając o powyższych ogólnych uwagach, spróbujmy przypatrzyćc się niektórym danym szczegółowym.

O wzroście człowieka decyduje jego kościec, osiągający właściwy sobie wymiar około dwudziestu kilku lat życia. W starszym wieku może on ulegać pewnemu skurczeniu, bądź wskutek atrofii kręgów, bądź wskutek garbienia się spowodowanego osłabieniem mięśni. Skład chemiczny kości czlowieka ulega pewnym zmianom, tak iż ich konsystencja staje się mniej zwarta. Stąd też, u ludzi starszych wzrasta niebezpieczeństwo złamania kości. Pogorszenie płynności ruchów, tak charakterystyczne dla niektórych starszych osób, spowodowane bywa często przebytymi chorobami stawów. Osłabienie dziąseł i choroby zębów bywają spowodowane zwykle różnymi zaniedbaniami w odżywianiu się i $w$ higienie jamy

- Tenże, 19.

7 Tenże, 42.

8 K. W. Schaie, Reflections on paper by Looft, Peterson and Sparks: Towards an ageless, society? „Gerontologist” 13 (1973), 31-35; także: J. B. N e s s e 1roade, H. W. Reese, Life-Span Developmental Psychology, in: $\mathrm{K}$. W. Sc ha i e (ed.), Methodological Issues, New York 1973, 3 seq.

"Cyt. za: L. H. Getze, The subject is you: Modern Maturity. „Publication of The American Association of Retired Person" Vol. 22, No. 6, 1979-1980, 44. 
ustnej. Ujemne skutki może również powodować ścieranie się szklîwá, prowadzące następnie do choroby zębów i ich zniszczenia.

Obok zjawisk deterioryzacji, gdy chodzi o kościec człowieka w starszym wieku, można zauważyć niekiedy powiększanie się niektórych części miękkich w późniejszych latach życia, np. nieznaczne powiększanie się nosa czy uszu. Zmiany te są wystarczające, aby człowiek stawał się mniej pewny siebie, bardziej ostrożny a nawet nieco zmartwiony, gdy znajdzie się w towarzystwie młodych.

Największą siłę mięśni osiąga człowiek między 25 a 30 r. ż. Potem elastyczność mięśni spada przy równoczesnym wzroście tkanki łącznej. Spowodowane to jest zmianami w cząsteczkach białka, co nadaje starszemu człowiekowi charakterystyczny ,zniszczony" wygląd po 50 r. $\dot{z}$.

W działaniu mięśni prążkowanych, czynnych przy każdorazowym ruchu i zależnych od woli człowieka, zachodzą dość znaczne różnice indywidualne. Mogą one zachować przez długi czas sprawność dzięki iç systematycznemu ,używaniu” oraz ćwiczeniom gimnastycznym. Ćwiczęnie bowiem jest obowiązującą zasadą, nie tylko w okresie rozwojowym, w adolescencji, ale i później, ażeby podtrzymać sprawność mięśni i. calego organizmu.

Mięśnie gładkie, w przeciwieństwie do mięśni prążkowanych, działają automatycznie i nie zależą od świadomości człowieka. Kieruje nimi tzw. autonomiczny układ nerwowy. Dlatego też, z wyjątkiem mięśni naczyń krwionośnych, mięśnie gładkie działają normalnie aż do późnej starości.

Samopoczucie człowieka zależy przede wszystkim od zmian w sprawności mięśni prążkowanych. Te zaś, jak to zaznaczyliśmy, wymagają systematycznych ćwiczeń ruchowych dla podtrzymania ich elastyczności i odpowiedniej siły.

Skóra starszego człowieka pokrywa się zmarszczkami i wiotczeje. Spowodowane to bywa utratą podskórnej warstwy tłuszczu, niepotrzebnie nagromadzonego kiedyś oraz odżywianiem się niewspółmiernym do procesów spalania. Poza tym, tkanki skóry starszego człowieka tracą również zdolność wchłaniania wody, stają się cieńsze i zgęszczone, co także wpływa na marszczenie się skóry. Ponieważ zaś skóra jest elementem organizmu najbardziej widocznym, dlatego też wszelkie niekorzystne zmiany w jej wyglądzie mogą bardzo ujemnie wpływać na samopoczucie starszego czlowieka oraz na tzw. obraz samego siebie. Nie jest to jednak regułą. Zmiany cielesnej aparycji, mimo że są częśćciowo niezależne od człowieka, niekoniecznie muszą wpływać ujemnie na psychikę. Wszystko zależy od świadomych procesów adaptacyjnych, jakie dana jednostka swym zewnętrznym zmianom przeciwstawia. Może.im 
bowiem częściowo zapobiegać, może je tuszować, a może je też po prostu pogodnie akceptować.

Dla zdrowia bardzo ważny jest sposób odżywiania się i właściwie przebiegające procesy trawienia. W starszym wieku zmysł smaku i powonienia nieco słabną, dlatego też osoba przyrządzająca posiłki powinna dbać o właściwy zestaw pokarmów. Chodzi o zgodne z zasadami dietetyki dobrane proporcje białek, węglowodanów, tłuszczów, soli mineralnych a zwłaszcza witamin, wzmacniających samoobronę organizmu. Układ trawienny jest mniej podatny na starzenie się, aniżeli inne układy i narządy. Niemniej, w wieku starszym gruczoły wydają mniej śliny i o mniejszej zawartości ptialiny. Również żołądek wydziela nieco mniej soków trawiennych i enzymów, tak ważnych w procesie trawienia. Stąd należy dbać o pokarmy lekko strawne, zawierające mało tłuszczów zwierzęcych i soli.

Emocjonalny stan podczas jedzenia i trawienia odgrywa dużą rolę. Takie uczucia, jak: gniew, wzburzenie, przykrość, strach, podniecenie pogarszają nie tylko apetyt, ale wpływają również na układ wydzielania wewnętrznego. Może to powodować obstrukcje, brak apetytu, nudności i ogólnie słabszą reakcję trawienną.

$\mathrm{O}$ ile młodsze organizmy łatwiej znoszą zmienną temperaturę, o tyle starszy człowiek ma trudności ze znoszeniem podwyższonej ciepłoty. Wolniej także reaguje na zimno, a w ogóle, trudniej mu przychodzi zaadaptować się do innego klimatu, tj. do ciepła, zimna, wilgotnoścí, wiatru, nagłych wahan ciśnienia atmosferycznego, itp.

Gdy chodzi o napoje, to - zdaniem specjalistów - należy wziąć pod uwagę to, że po 60 r. $\dot{z}$. główny filtr wszelkich płynów (nerki) tracą część tkanki ${ }^{10}$. Stąd też zbyt obfite napoje, a zwłaszcza ostre (np. alkohol), mogą spowodować pewne trudności, zaburzenia a nawet boleści.

Konieczne też jest ograniczenie spożywania soli, wyraźnie wpływającej na podwyższenie ciśnienia, szczególnie u osób cierpiących na nadciśnienie. Nadmiar soli dezorganizuje pracę nerek. Zaburzenia w funkcjonowaniu nerek, połączone $z$ zaburzeniami naczyniowymi, mogą prowadzić do „zaburzeń i anormalnego zachowania się" ${ }^{11}$.

Jedną z najbardziej zauważalnych oznak zaawansowanego wieku jest słabszy wzrok i słuch, bowiem soczewka oka już $\mathbf{w}$ wieku dorosłości staje się mniej przeźroczysta, mniej elastyczna a ponadto zmienia swój kształt. Przyczyną jest to, iż soczewka rośnie, nie pozbywając się starych komórek, które w zmienionym stanie chemicznym „zajmują"

10 Bromley, dz. cyt., 56.

11 Tenże, 56. Śzkodliwość alkoholu na narządy wewnętrzne, zwłaszcza na nerki, wątrabę i in. por. T. Bilikiew icz, Psychiatria kliniczna 1957, 35, 472, 500, 511. 
swoje pierwotne miejsce ${ }^{12}$. Zmiana ogniskowej w soczewce sprawia, że ok. 50 r. ż. wielu musi już nosić okulary korekcyjne, poprawiające długość wzroku. W dalszych latach zmienia się, tj. zmniejsza się średnica źrenicy, co ogranicza ilość światła wpadającego do oka. Zarówno słabszy dopływ krwi (oko ma tzw. tkankę bradytroficzną, w której wymiana substancji odżywczej odbywa się na drodze dyfuzji, a nie poprzez naczynia włosowate), jak i zanik komórek nerwowych mogą powodować zmniejszenie się ostrości spostrzeganego obrazu, słabsze rozróżnienie barw i gorszą adaptację siatkówki do ciemności. Oczy starszego człowieka, nawet gdy nie nosi okularów (noszenie okularów zwykle trochę cofa gałki oczne) wydają się zapadnięte. Tłumaczy się to częściową utratą tłuszczu w oczodołach. Kolor tęczówki jest nieco spłowiały. Rogówka jest mniej przeźroczysta, traci blask, natomiast zwiększa swoją grubość.

Atrofia tkanki nerwowej u nasady ślimaka w uchu wewnętrznym przytępia słuch starszego człowieka. Proces ten zaczyna się już w wieku dojrzałym a nasila $w$ miare przybywania lat życia.

Nie tylko zmiany w tkance nerwowej powodują gorsze słyszenie, ale także pewne urazy, przebyte choroby, dlugotrwałe przebywanie w intensywnym hałasie itp.

Wreszcie, ograniczona inteligencja danej osoby, nowe słownictwo, do którego ucho nie jest przywykłe, jak również jakiś niezwykły kontekst zdania, wpłynąć mogą na słabszy odbiór mowy u człowieka starszego ${ }^{\text {ts. }}$.

Wspomnieliśmy już wyżej o tym, że u starszego człowieka ulegają przytępieniu takie eksterioreceptory, jak powonienie i smak. Spowodowane to jest częściowym zanikiem opuszków węchowych i kubków smakowych.

Słabnie wrażliwość na ciepło, zimno a nawet na ból ${ }^{14}$, bowiem większośc tzw. progów wrażliwości wraz z wiekiem podnosi się, tj. słabnie reakcja zmysłów ${ }^{15}$.

Wreszcie, zmysł równowagi i postawy bywa u starszej osoby nieco

12 Bromley, dz. cyt., 57. Wspólezesny gerontolog Max Bürger dokonal podziału tkanki w zależności od stopnia ukrwienia. Wyróżnia on tkanki bradytroficzne, w których przemiana materii odbywa się na drodze dyfuzii oraz tkanki tachytroficzme, w których są naczynia wlosowate, wpływające na lepsza przemianę materii i bogatszy transport tlenu. Do tkanek bradytroficznych zalicza autor np. soczewke oka, rogówkę, zęby, chrząstki, kości, ścięgna i pewne warstwy tętnic. W wymienionych tkankach zachodzą najwcześniej zmiany zwyrodnieniowe, bo już $w$ trzeciej dekadzie życia człowieka (por. M. B ̈̇rger, Biomorfoza $i$ jej znaczenie $w$ procesie starzenia się $i$ stanach chorobowych, Warszawa 1965, 4-5).

13 Por. T. F a r r im ond, Prediction of speech hearing loss for older industrial workers, „Gerontologia” 5: 1961, 65-87.

14 Por. Brom le y, dz. cyt., 59.

15 Por. J. M. Mumford, Pain perception threshold and adaptation of human teeth, "Archives of Oral Biology" 10: 1965, 957-968. 
chwiejny. Stąd też, u starszego człowieka łatwiej jest o potknięcie się i upadek.

Jak widzimy, pewne zmiany $\mathrm{w}$ pobudliwości, zarówno w eksperioreceptorach, jak i proprioreceptorach, mogą odbić się na równowadze i na uwadze, pogarszać kontakt ze światem i zwalniać reakcje u starszego człowieka. Wszystko to wpływa na przedłużenie czasu, potrzebnego do zorientowania się w rodzaju bodźca oraz do odpowiedzi na niego. Stąd też wynika konieczność bycia bardzo cierpliwym wobec człowieka starego. Brak tej cierpliwości człowiek starszy bardzo przykro odczuwa a wszelki pośpiech drażni go i denerwuje.

Głos, mowa i oddychanie są ze sobą ściśle złączone. U człowieka starszego zmienia się nieco głos, tj. zwykle staje się on wyższy. Mowa zaś bywa niekiedy przerywana dłuższymi przestankami. Powodowane to jest $\mathrm{z}$ jednej strony pewną atrofią mięśni krtani, co wpływa na osłabienie strun głosowych, a $\mathrm{z}$ drugiej strony - zmianami w ośrodkowym układzie nerwowym i niewydolności płuc, trapionych chronicznym zapaleniem oskrzeli, co sprawia trudności w oddychaniu. Stąd człowiek starszy mówi wolniej, przerywa mowę dla złapania tchu.

Również jego proces myślenia nie jest już tak elastyczny, jak za młodu. Związane to jest $\mathrm{z}$ pewnymi procesami degeneratywnymi w niektórych ośrodkach mowy. Stąd też już na poziomie tzw. „mowy wewnętrznej”, czyli formułowania myśli i zdań przed ich wypowiedzeniem, mowa artykułowana może u starszego człowieka natrafiać na przeszkody.

Rytm oddechu u dorosłego człowieka $w$ stanie spoczynku wynosi od 15 do 18 razy na minutę. Przy każdym oddechu krew wzbogaca się $\mathrm{w}$ tlen, rozprowadzany potem przez naczynia włosowate do najdalszych partii organizmu. Szczególnie wrażliwym na niedobór tlenu jest mózg człowieka. Jakikolwiek brak tlenu odbija się natychmiast na procesach myślenia i mówienia, kojarzenia i rozumowania oraz na koordynacji sensoryczno-ruchowej. Człowiekiem owłada wówczas senność, Wspomnianą wyżej niewydolność mięśni, zauważałną już ok. 30 r. ż., należy prawdopodobnie przypisać zmniejszającej się wydolności układu oddechowego. W wieku starczym stan ten jeszcze się bardziej nasila.

Ludzi młodych i zdrowych denerwuje niekiedy spowolnione myślenie starszego człowieka, słabsza zdolność w wypowiadaniu słów, powtarzanie się itp. Wyrażanie $\mathrm{z}$ tego powodu swego niezadowolenia zawsze starszego człowieka boli, upokarza, onieśmiela a nawet skłania go do wycofywania się z publicznych wystąpień. Kapłan może ten właśnie brak odczuwać w starszym wieku jeszcze bardziej, ponieważ przemawianie jest jedną $z$ głównych funkcji jego powołania. Przed zaciągnię- 
ciem kompleksu ratuje go wewnętrzne wyrobienie i myślenie realistyczne.

Wspomniano już o funkcji rozprowadzania tlenu, jaką spełnia w organizmie krew. Swój ruch, czyli krwiobieg, zawdzięcza ona działalności serca, które jest naturalną pompą, a zarazem głównym organem układu krwionośnego. Puls serca u człowieka w stanie wypoczywania wynosi 72 uderzenia na minutę ${ }^{16}$. U człowieka $\mathrm{w}$ starszym wieku puls jest nieco przyspieszony. Rytm serca jest jednak nie tylko zależny od wieku, pozycji ciała, aktywności ruchowej, ale również od stanu emocjonalnego. U osób podnieconych, zarówno radosną jak i smutną wiadomością, puls serca jest szybszy. Podobnie, gdy człowiek jest przerażony lub zgniewany.

U starszego człowieka ciśnienie krwi zwykle się podwyższa. Jako przyczynę tego wskazuje się na zgrubienie ścianek tętnic oraz ich zwapnienie. Zwłaszcza to ostatnie, gdy dotyczy tętnic doprowadzających krew do mózgu, bywa w zaawansowanym wieku szczególnie groźne ${ }^{17}$.

Toteż wszelkie silniejsze stany emocjonalne u starszego czlowieka, ze względu na mniejszą elastyczność i zdolność adaptacji jego tętnic, mogą doprowadzić do pęknięcia naczyńka. Przypadek taki jest zawsze bardzo groźny, ilekroć dochodzi do uszkodzenia naczyńka w mózgu. Powoduje to zwykle uszkodzenie jakiegoś ważnego ośrodka w mózgu dając najczęściej objawy porażenia ruchowego, a nierzadko nawet kończy się to śmiercią.

O biologicznym podłożu cech temperamentu człowieka i o jego reakcjach emocjonalnych decyduje układ nerwowy i układ wydzielania wewnętrznego. Mimo że układy te są zasadniczo wrodzone, to jednak cechy temperamentalne są tylko częściowo niezmienne ${ }^{18}$. Zależy to $w$ dużej mierze od środowiska wywierającego wpływ na człowieka. Toteż cechy temperamentu mogą być nie tylko opanowane, ale i rozwijane, i w

16 Tak informuje Bromley, dz. cyt., 62.

Warto przy tej okazji podać kilka danych n.t. układu krwionośnego w organiźmie człowieka dla porównania ich $\mathrm{z}$ odnośnym stanem $\mathrm{w}$ wieku starczym, emerytalnym.

Objętość krwi u dorosłego człowieka wynosi ok. 5 litrów. Puls u mężczyzny wynosi 68-76/min., u kobiety zaś $74-80 / \mathrm{min}$. Każdy puls wypiera $100 \mathrm{~g}$ krwi $\mathrm{z}$ serca, tj. 24 tys. $\mathrm{kg} \mathrm{w}$ ciągu 24 godzin. Przy dużym wysiłku, odpowiednio: 400 $\mathrm{g}-80$ tys. kg, ale tylko przez parę minut. Na minutę serce przetacza 3,5 do 6 litrów krwi. Szybkość biegu krwi: aorta - $500 \mathrm{~mm} / \mathrm{sek}$., naczynie włosowate $0,5 \mathrm{~mm} / \mathrm{sek}$. I jeszcze, dla porównania podamy różnice pulsu u człowieka w różnych etapach jego życia. I tak, u noworodka - 140/min., w 5 r.ż. -100 do $110 / \mathrm{min}$., dzieck o - ok. $90 / \mathrm{min}$., dorosly - ok. $70 / \mathrm{min}$., starzec - ok. 80/min., por. Encyclopaedia Britannica, Landon 1962, vol. III, 739-747; vol. V, $721 \mathrm{C}-721 \mathrm{~F}$.

${ }_{17} \mathrm{I}$. K. Z Z la, Feelings about age older People, "Gerontologist Journal" 17: $1961,65-68$.

18 Por. A. Eliasz, Temperament a system regulacji stymulacji, Warszawa $1981,17 \mathrm{n}$. 
jakiejś mierze zmieniane. Czynnik wieku może tutaj również odgrywać rolę $\mathrm{w}$ połączeniu $\mathrm{z}$ tzw. doświadczeniem życiowym. Zmiany te mogą być zarówno pozytywne, jak i negatywne.

Wydaje się, zgodnie $\mathrm{z}$ dzisiejszym stanem wiedzy, że gdy chodzi o zachowanie się człowieka, jego doświadczenie i stany pobudzenia czy wygaszania uczuć, dominujący wpływ ma podwzgórze i zależna od niego przysadka mózgowa ${ }^{19}$. Przy ich ,pomocy” może się człowiek, zarówno emocjonalnie rozbudzić, jak i rozbudzone uczucia odpowiednio wyhamować a nawet wygasić (wpływając na to myślą i wolą).

Znajomość tego mechanizmu jest ważna w procesach adaptacji. Porównanie zapisu EEG ossób młodszych z zapisem od osób starszych, w odpowiedzi na pobudzenie, wykazuje że u młodszych jest on wyraźniejszy aniżeli u starszych. Można by stąd wywnioskować, że u osób w starszym wieku istnieje nieco niższy poziom pobudzenia. Tłumaczy to pewną „bezwładność” reakcji, zakłócającej późniejsze bodźce ${ }^{20}$. Jest to jeszcze jeden wskaźnik, wyjaśniający spowolnienie reakcji u człowieka starszego.

Podwzgórze i przysadka mózgowa, jako wyższy ośrodek koordynacyjny autonomicznego układu nerwowego, pobudzony sytuacją kontroluje (tzn. ma wpływ na reakcję emocjonalną).

Ale tenże sam ośrodek działa również w sposób odruchowy i niezależny od człowieka, od jego woli, przygotowując organizm do sprostania pewnemu zadaniu, względnie do pokonania niebezpieczeństwa.

Część podwzgórza działa kierowniczo na układ sympatyczny mobilizując organizm do określonego wysiłku. Zwykle związane to jest $\mathrm{z}$ pewnym napięciem, uczuciem bólu, strachu, podniecnia, złości itp. Organizm pod tym wpływem reaguje bowiem przez przyspieszenie bicia serca, zwężenie tętnic, hamowanie ruchów żołądka i jelit, rozszerzenie oskrzelików i źrenic, rozpad glikogenu na glikozę w wątrobie, zwiększenie wydzielania gruczołów potowych. Mogą ponadto temu towarzyszyć takie obja-

19 Bromley, dz. cyt., 65.

20 Por. J. E. Birren, H. A. Imus and W. F. Windle, The Process of Aging and Nervous System, Oxford 1959, $5 \mathrm{n}$.

Chodzi tutaj o tzw. neural noise hypothesis, tj. mnogość bodźców i szybkość w ich następowaniu lub też niższy próg (threshold) pobudzenia wskutek zamierania komórek nerwowych. Według innej hipotezy, tzw. funkcjonalnej (excitability hypothesis) owa bezwładnюść reakcji powstaje wskutek słabszej spostrzegawczości. lub zaburzeń w synapsach, por. H. J. Ey senck, W. Arnold, R. M eilii, Encyclopedia of Psychology, New York 1979, 36; por. także: E. R. W. F. Cros S$\mathrm{man}$ and J. Szafran, Changes with age in the speed of information intake and discrimination, "Experientia”, Suppl. 1956 (4), 128-135; J. S z afran, Age differencies in the rate of gain of information, signal detection strategy and. cardiovascular status among pilots, "Gerontologia" 12: 1966, 6-7; tenże: Psychological studies of aging in pilots, in: G. A. T a lla nd, Human aging and behaviour, New York 1968, 37-74. 
wy, jak: napięcie mięśni, drżenie (tremor), ,gęsia skórka”, brak kontroli nad pęcherzem i zwieraczem odbytu.

Układ parasympatyczny działa w narządach zwykle przeciwstawnie do pobudzającego działania układu sympatycznego (np. układ sympatyczny przyspiesza działanie serca, a układ parasympatyczny pracę serca zwalnia). Ważną uwagę robi Bromley, że ,układy sympatyczny i autonomiczny są ściśle powiązane, a podwzgórze odgrywa rolę koordynacji ich działania. W uczuciach i emocjach, towarzyszących pobudzeniu układu sympatycznego odgrywają również rolę czynniki psychiczne" ${ }^{21}$. Przedłużające się stany napięcia uczuciowego są szkodliwe i mogą utrudniać prawidłowe przystosowanie się ${ }^{22}$. Stąd też starszy człowiek broni się przed zbyt silnymi bodźcami nerwowymi i uczuciowymi, zwłaszcza gdy chodzi o uczucia przykre i przeżycia bolesne.

Wreszcie, jeszcze jedna istotna uwaga, gdy chodzi o zmiany w komórkach nerwowych, mianowicie że one zamierają, ale nie są w stanie się regenerować. Bromley formułuje $\mathrm{w}$ tym względzie takie stwierdzenie: „Niektóre części włókien mogą regenerować się, ale samej k o m ó rki nerwowej nie można zastą pi ć" ${ }^{23}$.

To zjawisko - acz nie chorobowe - jest nieodłączne od biologii mózgu człowieka od wczesnych lat jego dorosłości. Skutki tego są jednak szczególnie znamienne dla starości.

Nowe „zapisy" w korze mózgowej są u starszego człowieka utrudnione, dlatego operuje on w coraz szerszym zakresie zapisami dawnymi, tj. doświadczeniem, przeżyciami dawno minionymi czy też wspomnieniami z młodości. Warto jeszcze dodać, że spowolnienie myślenia u starszego człowieka jest nie tyle spowodowane wolniejszym przewodzeniem impulsu nerwowego, co dłuższą ,organizacją procesów w korze mózgowej" - jak stwierdza D. B. Bromley ${ }^{24}$.

Jest oczywiste, że ten krótki przegląd niektórych aspektów procesu starzenia się organizmu ludzkiego jest ogólny i niekompletny, ale wystarczający, aby zdać sobie sprawę z zasadniczej różnicy między dwoma pojęciami: chorobą i starzeniem się (które jest odmianą zdrowia) ${ }^{25}$.

\footnotetext{
21 B romle y, dz. cyt., 68.

22 Tamże.

$2 s$ Tamże, 70 .

24 Tamże.
}

25 Warto tutaj odnieść się do definicji zdrowia, przyjętej przez Swiatową Organizację Zdrowia (WHO): „Zdrowie jest to stan całkowitego zadowolenia (Wohlbefinden) fizycznego (körperlicher), psychicznego (geistiger) oraz społecznego (sozialer), a nie tylko brak choroby i niedyspozycji", por. P. Diepgen, G. Gruber, H. S chadenw ald t, Der Krankheitsbegriff, seine Geschichte und Problematik: Prolegomena einer Allgemeinen Pathologie. Handbuch der Allgemeinen Pathologie, Bd. I (Hrsg. v.H.W. Altmann, F. Büchner i in.) 1969, 1 n; K. E. R ot h s c h u h (Hirsg.), Was ist Krankheit? Erscheinung, Erklärung, Sinngebung 1975. C. F. W e i t z s ä c k e r, Kritische Medizin. Zur Theorie-Praxis-Problematik der Medizin und der Gesundheitssystheme des Krankenheitsbegriffs, „Therapie der Gegenwart” 115: 1976, 1643 n. 
Choroba jest zawsze wtargnięciem jakiegoś czynnika obcego, burzącego homeostazę, zdrowego skądinąd, organizmu. Jest zaburzeniem, którego przyczyna tkwi zasadniczo nie w samym organizmie, ale pochodzi od czynników spoza organizmu. Natomiast starzenie się jest po prostu procesem zużywania się organizmu, zarówno pod względem strukturalnym, jak i funkcjonalnym. Można by zatem ten proces przyrównać do zmęcze-

Definicja zdrowia wg WHO, jak to stwierdzają uczeni, ukazuje raczej stan utopijny, aniżeli rzeczywisty, nie dlatego, że podkreśla sferę subiektywnego poczucia (co niekiedy jest bardzo mylne, np. gdy ktoś ma raka, ale wcale tego nie odczuwa, czy tym samym nie jest on chory? ...czy jest zdrowy?), ale dlatego, że podkreśla jakiś stan zdrowia maksymalny (optymalny), który jest stanem nierealnym. Toteż Weitzsäcker C. F. twierdzi, że gdybyśmy uważali za zdrowego tego, kto odpowiada definicji zdrowia wg WHO, a odejście od tej normy uważali za chorobę, to nie znaleźlibyśmy żadnego czlowieka zdrowego, por. C. F. W e it z$\mathrm{s}$ ä c k e r, dz. cyt., 327 .

Inne definicje zdrowia:

Zdnowie, jako pewna harmonijna całość. Według U. Eibacha, nalleżaloby definicję zdrowia wg WHO uzupełnic. W swym artykule pt. Gesundheit und Krankheit. Anthropologische und ethische Uberlegungen zur Definition der Begriffe und zum Sinn von Gesundheit und Krankheit, w: In libertatem vocati estis, dz. zb. „Studia Moralia XV”, pod redakcją H. B oela ars, R. Tremblay. Academia Alfonsiana, Roma 1977, 599-624, proponuje za innymi autorami następującą definicję zdrowia: „Zdrowie zatem, jest to taki stan, który cechuje sensowna i wewnętrznie zgodna c ałość lub jedność (Einheit), jaką tworzy harmonia pomiędzy jednostką a jej otoczeniem społecznym i fizycznym oraz harmonia, istniejąca wewnątrz danego organizmu i między danym organizmem a jego otoczeniem fizycznym i społecznym, umożliwiająca zgodne współistnienie między tymi sferami".

Definicja zdrowia wg Karla Bartha:

Według K. Bartha zdrowie, to „Kraft zum Menschsein”, czyli posiadanie dostatecznej siły, aby żyć jak człowiek (tł. moje), por. K. B a rth, Kirchliche Dogmatik, Bd III, 4, 1951, s. 406.

Życie bowiem jest rzeczywistością celowo ustrukturalizowaną. Nie wy'starczy jednak sama tylko harmonia biologiczna. Potrzebna jest wizja sensu i celu w życiu, aby czuć się naprawdę zdrowym. To właśnie oznacza określemie Bartha: „Pasiadanie dostatecznej siły, aby żyć jak człowiek", tj. po ludzku, ze świadomością, że realizuje się wszystkie aspekty swojego przeznaczenia.

Por. także: D. Schultz, Growth Psychology. Models of the healthy personality, New York 1977, $1 \mathrm{n}$.

Definicje choroby wg U. Eibacha:

Wedlug U. Eibacha, ,chorobą byłoby to wszystko, co psuje harmonijną regulację pnocesów życiowych $\mathrm{w}$ organizmie lub narusza tę regulację w stosunku do otoczenia spolecznego (ludzkiego) czy fizycznego (przyroda), stanowiąc jakąś przészkodę lub nawet niszcząc warunki osiągnięcia celu w życiu", por. U. Eiba c h, $d z$. cyt., 606. W/w autor sądzi, że nawet cierpiący lub kaleki człowiek może być uznany za zdrowego, gdy potrafi żyć ze swoją chorobą, kalectwem i nadawać temu wyższy sens, adaptując się do komkretnej sytuacji.

Tego rodzaju pogląd bardzo nam odpowiada. Mógłby on mieć również zastosowanie do życia na emeryturze, gdy trzeba się „zgodzić na siebie” i ma drugich. Owa z g oda byłaby wynikiem świadomej adaptacji, decydującej zarazem o wewnętrznym spokoju a nawet o szczęściu.

Warto tutaj wyjaśnić, że tzw. choroba psychiczna, którą niekiedy zbyt latwo przypisuje się człowiekowi w starszym wieku, nie dotyczy jednoczesnego schorzenia duszy. Zdaniem współczesnych filozofujących lekarzy, a zwłaszcza psychiatrów, choraba psychiczna wskazuje jedynie na taką chorobę ciała, która w swoisty spasób utrudnia działanie duszy chorego człowieka, por. G. R oth, Psychose-Somatose. Tomanische Gedanken und thomistische Uberlegungen in der gegenwärtigen Psychiatrie, in: „Virtus politica”, Wien 1974, n. 
nia, z którego organizm coraz słabiej șię regeneruje. Niewątpliwie ów „proces zmęczenia” musi się kiedyś skończyć i to można nazwać śmiercią ze starości. Zwykle jednak człowiek przechodzi w życiu różne choroby, których skutki się kumulują i w konsekwencji przyspieszają śmierć ${ }^{26}$.

Niektórzy sądzą, że długość życia jest zaprogramowana w żywej komórce. Inni, jak Gompertz, sądzą, że tzw. krzywe śmiertelności są funkcją czynników wewnętrznych i zewnętrznych. Współczesna medycyna skłonna jest widzieć proces starzenia się w świetle ,wysuszania się" organizmu. Źródłem tego wysuszania się, zdaniem dra Juliusza Blicharskiego, byłby zanik gruczołu grasicy (thymus) itp.

W przeglądzie procesów starzenia się organizmu na poszczególnych jego odcinkach zaznaczaliśmy raz po raz, jakie skutki wywierają te procesy na psychikę starzejącego się człowieka. Nie ulega bowiem wątpliwości, że wszelka niesprawność organiczna niepokoi, zasmuca a niekiedy wprost obezwładnia. Ponadto, zmniejszając efektywność działania, staje się ona przyczyną różnych stanów negatywnych w sferze emocjonalnej. To z kolei może wywoływać różne zaburzenia organiczne a nawet choroby.

Starzenie się kapłana pod pewnymi względami wydaje się być specyficzne. Jego praca przebiega wśród wielu napięć nerwowych i emocjonalnych.

Dlugotrwałe siedzenie w konfesjonale zwykło odbijać się ujemnie na procesach trawienia i krążenia krwi. Publiczne przemawianie pociąga za sobą chorobę gardła (tzw. clengyman's sore).

Spełnianie funkcji kapłańskich w zimnym kościele lub na powietrzu prowadzi do częstych zaziębień czy też do schorzenia dróg moczowych.

To wszystko, oczywiście, nie przedłuża życia. Jego śmierć jest często nagła, według przysłowia łacińskiego: „Subitanea mors, sacerdotum sors”, albowiem spełniane obowiązki kapłańskie obciążają przede wszystkim jego serce i system nerwowy.

${ }^{26}$ Ze względu na zmiany biopsychiczne u człowieka interesujące jest zestawienie dokonane przez D. B. B r o m l e y'a, dz. cyt., 24:

1) Okres rozwojowy (do 21 r.ż.): Zmiany są intensywne i wyraźne, wpływające na zachowanie.

2) Okres dojrzałości (21-55 r.ż.): Zmiany są mniej widoczme, ale są i kumulują Okres ten dzieli się na: się.

a) wczesny wiek dojrzaly $(21-25$ r.ż.

b) średni wiek dojrzały $(25-40$ r.ż.)

c) późny wiek dojrzały (40-55 r.ż.)

3 Starość (od 70 r.ż. wzwyż): Zmiany są znowu wyraźniejsze i mają znaczny wpływ na życie czlowieka

Okres starości dzieli się na trzy fazy:

a) przed wycofaniem się z pracy $(55-65$ r.ż.)

b) przejście na emeryturę ( $65 \mathrm{r} . \dot{z}$. lub później)

c.) wiek starczy (od $70 \mathrm{r} . \dot{z}$. do maksimum 110 lat) 
Mimo to, przejście kapłana na e meryturę - jak to jeszcze zobaczymy - dokonuje się zwykle dopiero po dłuższym wahaniu i przyjmowane bywa zwykle jako pewna ostateczność.

\section{PROBLEM PRZECHODZENIA KAPEANOW NA EMERYTURE}

Przechodzenie na emeryture jest w mniejszym lub większym stopniu zawsze jakimś problemem. Jest ono problemem $w$ dwojakim znaczeniu:

a) materialno-finansowym

b) psychologiczno-adaptacyjnym

Gdy chodzi o kapłanów, pierwszy problem regulowany bywa przez odpowiednie Ustawy Synodów Diecezjalnych lub rozporządzenia biskupów ordynariuszy. Drugi problem jest przede wszystkim sprawą osobistego nastawienia.

$\mathrm{Na}$ wstępie konieczne są pewne ustalenia terminologiczne. Słowo „emerytura" (łac. emeritus = wysłużony, zostający w stanie spoczynku) jakkolwiek bywa w kołach księży powszechnie używane, nie ma jednak tego samego znaczenia, jakie ma ono w społeczeństwie. W świecie pracy zarobkowej oznacza ono zaprzestanie pracy zawodowej i wycofanie się z pełnienia dotychczasowej funkcji, będącej podstawa utrzymania siebie i rodziny. Kapłan, przechodzący na emeryturę, pozostaje najczęściej nadal jeszcze czynnym na polu duszpasterskim i naukowym. Składa natomiast jedynie odpowiedzialność administracyjną swego urzędu. Wobec tego termin „emerytura" stosuje się do kapłana raczej w sensie przystosowanym (accomodated sense) ${ }^{27}$. Po wtóre, przejście na emeryturę może mieć podwójny charakter: dobrowolny (optional) albo obowiązkowy

27 Problem terminologii, dotyczącej emerytury wymaga obszerniejszego wyjaśnienia. Polskie terminy „emerytura" (od łac. emereo, co znaczy: zasłużyé, wysłużyé pensję), „iść na emeryturę”, „żyć na emeryturze”, stosowane do starszych księży są nieadekwatne. Nie wyrażają bowiem w pełni faktycznego stanu zaistniałego w wyniku przekazania administracji młodszemu konfratrowi. Jedną z najgłówniejszych funkcji - odprawianie Mszy św. - ksiądz-emeryt nadal wykonuje. Nie wycofuje się on też z niektórych innych pomocy duszpasterskich. Powstaje problem, jak nazwać tę nową sytuację? Wyrażenia takie, jak: „rezygnacja z probostwa”, „złożenie odpowiedzialności administracyjnej za parafię", czy starsze wyrażenia, jak: „ksiądz w stanie spoczynku”, „wycofanie się z życia publicznego", „ksiądz na starość osiadł na dewocji" itp., są opisowe i wielosłowne, chociaż lepiej oddają ową „częściowość” emerytalnej rezygnacji. Trudno jest znaleźć pojedyńczy termin, wyrażający pel̉ną treść znaczeniową faktu przejścia księdza na emeryturę. Trzeba nam zatem pazostać przy terminie dwusłownym: „Ksiądz emeryt” lub „Ksiądz na emeryturze" - w wyrażeniu trzysłownym.

W języku amgielskim poradzono sobie z odnośną terminologią o tyle, że księdza na emeryturze nazywa się po łacinie: „Pastor Emenitus” lub ściśle po angielsku: „Senior Priest”, zaznaczając w ten sposób odmienność znaczeniową statusu emerytalnego księdza, tzn., że jest nadal w pewnym sensie proboszczem (Pastor) i nadal pozostaje kapłanem tylko trochę starszym (Senior Priest). 
(obligatory) przy czym, obowiązek przejścia na emeryturę dotyczy wystąpienia $\mathrm{w}$ odpowiednim czasie z wnioskiem o rezygnacje „,nie później, aniżeli po skończonym 75 r.ż.” ${ }^{28}$. Biskup ordynariusz, na którego ręce wniosek o przyjęcie rezygnacji bywa składany, rozważa każdy poszczególny przypadek. Następnie, albo go akceptuje, albo na jakiś czas go uchyla. To samo dotyczy rezygnacji dobrowolnej (optional).

Ważniejszą rzeczą, aniżeli terminologia, jest samo rozwiązywanie życiowych zagadnień, związanych $\mathrm{z}$ przejściem księży na emeryturę. Ze względu na to, że w tym studium badane były dwie grupy księży, tj. w Stanach Zjednoczonych i w Polsce, spróbujemy już w tym miejscu porównać ogólne warunki rozwiązywania problemów emerytalnych księży w obu krajach.

Gdy chodzi o Stany Zjednoczone, istnieje obszerny „Raport” Komisji Biskupiej dla Spraw Życia i Posługiwania Księży, dotyczący problemu emerytury kapłanów (A Report on a Study of Clergy Retirement) w Stanach Zjednoczonych A. P. z roku $1979{ }^{29}$.

W programie opieki nad księżmi, przechodzącymi na emeryturę, przyjęto zasadę tzw. „hierarchii potrzeb” według A. H. Maslowa ( $\dagger 1970)$.

Maslow ujmuje potrzeby ludzkie w następującej kolejności:

1. Potrzeby biologiczne (pokarm, napój, powietrze, sen, seks);

2. Potrzeby bezpieczeństwa (spokój, stabilizacja, obrona, porządek, wolność od lęku i strachu);

3. Potrzeby przynależności i miłości (przynależność do grupy, miłość: możność kochania i pewność bycia kochanym);

4. Potrzeby szacunku (od siebie samego, od innych);

5. Potrzeby samorealizacji (rozwinięcie wszystkich swych talentów i możliwości);

Pod koniec życia (r. 1970) A. H. Maslow wymienił jeszcze „potrzebę transcendencji”, wyższą od „potrzeby samorealizacji”. Autorzy programu dla księży-emerytów w USA uwzględniają dalszy rozwój życia duchownego w okresie lat emerytalnych starszego księdza ${ }^{30}$.

${ }^{28}$ Por. Dekret Soboru Watyk. II Christus Dominus, zawierający ogólna zasadę, dotyczącą dobrowolnej rezygnacji, tj. aby ,ze względu na podeszły wiek czy $\mathrm{z}$ innego ważnego powodu... zglosili rezygnację ze stanowiska czy to samorzutnie, czy za wskazaniem miarodajnej władzy", por. Konstytucje, Dekrety, Deklaracje, Poznań 1968, 242, n. 21;

Por. też: Motu Proprio Paw la V I Ecclesiae Sanctae akreślający biliżej pastanowienie dekretu Christus Dominus, odnośnie do wieku, w którym należy prosić o przyjęcie rezygnacji. Norma wieku dla przejścia obowiązkowego na emeryturę opiewa na 75 r.ż. Obowiązuje ona zarówno biskupów, jak i proboszczów, por. $A A S, 58: 1966,763$, n. 11 ; oraz 768, n. $20, \S 3$.

29 Por. FULLNESS IN CHRIST. A Report on a Study of Clergy Retriement. Washington D. C. 1979, 55 (Slkrót: RSR).

${ }^{80}$ RCR, 7; por. też J. J. Braun, D. E. Linder, Psychologŷ Today, New York 1979, 374. 
W każdym razie, wydaje się rzeczą bardzo słuszną kierowanie się hierarchią potrzeb w rozwiązywaniu problematyki życia księdza na emeryturze. Ważna jest ich kolejność zaspokajania przez powołane do tego czynniki kościelne, którym kapłan $\mathrm{z}$ racji swego powołania podlega, zarówno na szczeblu diecezjalnym, jak i ogólno-kościelnym.

W oparciu o teorię potrzeb A. H. Maslowa oraz w oparciu o zasadę, że gratyfikacje wyższych potrzeb musi poprzedzać gratyfikacja potrzeb niższych, ustalono w Ameryce Płn., że w zaspokajaniu potrzeb księży emerytów będzie się uwzględniać najpierw tzw. potrzeby fundamentalne, a potem kolejno coraz wyższe, aż do potrzeb duchowych włącznie.

Potrzeby te ujęto w sześć punktów ${ }^{31}$ :

1. Pensja i pewne opłaty

2. Mieszkanie

3. Kontynuacja pracy duszpasterskiej

4. Przygotowanie do przejścia na emeryture

5. Opieka urzędowa nad kapłanami-emerytami

6. Pomoc w dalszym dojrzewaniu duchowym

Można również spojrzeć na wymienione wyżej sześć potrzeb kapłana emeryta - jak wspomniliśmy - jako na tzw. potrzeby fundamentalne. Uznać jednak potrzebę pensji emerytalnej, właściwego mieszkania, jakiejś dorywczej pracy duszpasterskiej i ogólnej troski o warunki życia materialne i duchowe kapłana na emeryturze ze strony władz diecezjalnych za tzw. potrzeby fundamentalne - wydaje się $\mathrm{w}$ obecnych czasach już nie wystarczające. Stąd też, Komisja Biskupia USA przedstawiła projekt jeszcze jednego programu, bardziej rozwiniętego, dotyczącego troski o kapłanów-emerytów, zarówno ze strony parafii, w której pracował, jak i ze strony diecezji, na terenie której służył wiernym. Chodziło o stworzenie kapłanowi-emerytowi prawdziwie godnej, a zarazem pogodnej starości. Stąd ustalono dwa stopnie programu:

1. Pierwszy stopień programu - potrzeby fundamentalne

2. Drugi stopień programu - potrzeby dodatkowe

ad 1) Chodzi o zaspokajanie tych potrzeb, które sa podstawowe a zarazem konieczne, by kapłan mógł swą emeryturę przeżywać godnie. Do nich należą następujące: pensja emerytalna i opłaty, dobre warunki mieszkaniowe, kontynuacja pracy duszpasterskiej w pewnym drobnym wymiarze, ewentualne przygotowanie kandydata do przejścia na emeryturę, opieka władz diecezjalnych nad kapłanem-emerytem i wreszcie jakieś wsparcie w dalszym rozwoju duchowym ze strony władz kościelnych.

3) $R C R, 10-11$. 
ad 2) Gdy chodzi o tzw. drugi program, to Komisja Biskupia pragnęła zaproponować pewne dodatkowe formy wdzięczności ze strony parafii, w której ksiądz-emeryt pracował lub pewne gesty ze strony władz diecezjalnych, którym ksiądz-emeryt podlegał. Chodzi o oznaki ludzkiej wdzięczności: pamięć o imieninach, o rocznicy święceń, o życzeniach świątecznych itp. okazjach, w których można wyrazić stałą wdzięczność, serce i zwykłą ludzką dobroć, życzliwość a nawet miłość.

Spróbujmy teraz rozważyć problem przejścia Księdza na emeryturę w świetle wymienionych wyżej sześciu punktów. Porównamy analogiczne sytuacje w USA i PRL:

- Pensja i pewne opłaty dla księży-emerytów w USA ${ }^{82}$ :

Wysokość pensji miesięcznej księdza-emeryta w USA kształtuje się w wysokości 200 do 600 dolarów i więcej. Nieco inaczej ksztaltuje się ona, gdy ten przebywa w Diec. Domu Księży Emerytów. A zatem, do stałej pensji emerytalnej dochodzą jeszcze pewne opłaty, uiszczane przez kurie biskupie, np. za udział w rekolekcjach, za pobyt w Domu Emerytów, opłaty $\mathrm{z}$ tytułu choroby lub kalectwa. Kuria biskupia uiszcza te opłaty niezależnie od tego, ile dany ksiądz otrzymuje z ubezpieczalni, do której wysyłał kiedyś regularnie składki równolegle ze składką na fundusz emerytalny w kurii. Gdyby bowiem tych pierwszych opłat tj. procentów i sum ubezpieczeniowych teraz go pozbawiono, „byłby on podwójnie karany" s8.

Powstaje pytanie, skąd w kuriach biskupich bierze się fundusz emerytalny?

Otóż, nie tylko z samych składek, które ksiądz z tytułu przyszłej emerytury obowiązany jest $w$ ciągu lat swego pełnoetatowego duszpasterzowania wysyłać do kurii biskupiej, ale z kilku innych jeszcze źródeł. Wśród nich są takie, jak: pewne kwoty pieniężne wysyłane $\mathrm{z}$ parafii czy instytutu, gdzie ksiądz-emeryt pracował do czasu przejścia na emeryturę. Następnie, doroczna kolekta zebrana w diecezji, fundusz dyspozycyjny diecezji i inne. W skład tych ostatnich wchodzą np. darowizny, kwoty ze spadków, ofiary z różnych parafii, procenty od legatów oraz jakieś okolicznościowe ofiary na cele diecezjalne, przeznaczane przez biskupa ordynariusza na fundusz emerytalny. Ponadto, w gre wchodzi również tzw. wysługa lat, co w niektórych diecezjach USA oblicza się następująco: za każdy miesiąc dolicza się 6.75 dolara, czyli np. za 40 lat pracy duszpasterskiej ksiądz-emeryt otrzymałby 3240 dolarów $\mathrm{z}$ tego tytułu. 
- Pensja emerytalna księży-emerytów w PRL ${ }^{34}$ :

Gdy chodzi o pensję emerytalną, otrzymywaną przez księży w Polsce, to poszczególne diecezje rozwiązują tę sprawę we własnym zakresie według norm ustalonych w Ustawach i Rozporządzeniach Diecezjalnych oraz zgodnie z aktualną koniunkturą gospodarczą w kraju. Niektórzy księża-emeryci mają emeryturę państwową, jako byli katecheci czy prefekci etatowi. Inni, z tytułu posiadanego ubezpieczenia (od dnia $1 \mathrm{~V} 1980 \mathrm{r}$. osoby duchowne $\mathrm{w}$ PRL zatrudnione $\mathrm{w}$ instytucjach kościelnych na podstawie umowy o pracę zostały objęte obowiązkowym ubezp i e c z e ni e m, por. Okólnik n. 6 Zakładu Ubezpieczeń Społecznych z dnia 31 III 1980 r.). Księża otrzymują także osobno pensję emerytalną, w kiórą nie wchodzą intencje mszalne.

\section{- Mieszkanie (USA) ${ }^{35}$ :}

Na wybór sposobu zamieszkiwania księdza-emeryta w USA wpływa zwykle wiele przyczyn, nie tylko materialnych, ale i emocjonalnych, charakteriologicznych, czy również stosunek do nowo przybyłego duszpasterza na plebanii lub stanowisko wiernych $\mathrm{w}$ parafii. W każdym razie, celem uniknięcia ewentualnych nieporozumień, ksiądz w większości wypadków woli jako emeryt, zamieszkiwać prywatnie, tj. we własnym domu lub mieszkaniu. Zwyczajnie też pozwala się księdzu samemu wybrać rodzaj zamieszkiwania. Starszy człowiek bowiem nie lubi, gdy się mu coś narzuca lub gdy się nim dyryguje. Bliskość kościoła zawsze w tym wyborze odgrywa ważną rolę.

Przeprowadzone przez ks. Waltera $H$. Jenne badania $w$ diecezjach USA nt. najczęściej wybieranych form zamieszkiwania księży na emeryturze wykazały, że większość księży-emerytów ma bądź własny dom, bądź co najmniej własne mieszkanie. Na 139 diecezji USA aż 60, tj. $43.2 \%$ podało tę formę zamieszkiwania swoich księży-emerytów.

\section{- Mieszkanie (PRL):}

W Polsce księża-emeryci mieszkają bądź na plebani w parafii, w której dotychczas pracowali, bądź w Diecezjalnych Domach Księży Emerytów, np. w Tarnowie, Lublinie, Krakowie, Kielcach, Wrocławiu, które autor miał sposobność zwiedzić. Niektórzy z księży mieszkają w domu sióstr zakonnych, w którym pełnią funkcję kapelana. Inni mieszkają przy jakimś klasztorze męskim na tzw. dożywociu. Wreszcie jeszcze

${ }_{34}$ Dane nt. warunków życia księży-emerytów w PRL czerpano z przeprowadzanych wywiadów z przedstawicielami adnośnych resartów $\mathrm{w}$ kuriach biskupich oraz z samymi księżmi emerytami.

$35 R C R, 60$. 
inni, i to nawet dość często, mieszkają przy swojej rodzinie np. przy siostrze, bracie, siostrzenicy itp. lub we własnym domu.

- Kontynuacja pracy duszpasterskiej (USA) ${ }^{36}$.

Sytuacja księdza-emeryta $\mathrm{m}$. in. jest o tyle różna od analogicznej sytuacji pracownika świeckiego, że kapłaństwo jest specjalnym powołaniem. Oznacza to coś więcej aniżeli określone wykształcenie i zawód. Istnieje w Ameryce takie powiedzenie: "To die with their boots on", to znaczy „umrzeć, mając buty na nogach”. Ksiądz bowiem, chce pracować jak długo mu siły na to pozwalają. Toteż badania wspomnianego już ks. W. H. Jenne potwierdziły zarówno sam fakt kontynuowania jakiejś pracy kapłańskiej u księży-emery.tów, jak i jej różnorodność. Wymieniano następujące funkcje: posługa duszpasterska w zmniejszonym wymiarze, kapelaństwo (np. u sióstr zakonnych), udzielanie rekolekcji, poradnictwo duchowe, głoszenie konferencji, spowiadanie, pomoc w nauczaniu religii, odwiedzanie szpitali, kierownictwo duchowne, nauki dla konwertytów, praca pisarska, wreszcie - choroba.

Ponadto, poszczególne kurie biskupie informowały, że do wglądu księży-emerytów wywiesza się listę z propozycjami pomocy duszpasterskiej. Księża mogą rozważyć różne oferty, pójść pod dany adres (zatelefonować) i bliżej zapoznać się z rodzajem pracy. Mogą to uczynić na długo przed oficjalnym przejściem na emeryturę, by zorientować się w różnych propozycjach. Wielu księży, w miarę sił i czasu, korzysta z możliwości spieszenia z kapłańską posługą.

- Kontynuacja pracy duszpasterskiej (PRL):

U nas każdy kapłan jest przekonany, że otrzymana $w$ dniu święceń władza pasuje go na dozgonną aktywność kapłańską. Kapłan polski wie, że podobnie jak jego kapłaństwo nie wygasa wraz z przejściem na emeryturę, tak i jego funkcje, do których ono uprawnia, nie powinny ulec zaprzestaniu. Chyba, że go do tego zmusi choroba. Toteż kapłani-emeryci nie wyłączają się z pracy duszpasterskiej. Wielu z nich przyjmuje funkcje kapelanów sióstr zakonnych. Przede wszystkim jednak sa oni nieocenionymi s p o w i e d n i k a mi, zarówno konfratrów, jak i wiernych, którzy bardzo sobie cenią ich doświadczenie oraz systematyczne zasiadanie w konfesjonale o określonej godzinie. Spowiadanie się u starszych kapłanów ceni sobie przede wszystkim młodzież, która swe problemy lubi powierzać tym kapłanom, którzy jej osobiście nie znają, a przy tym potrafią udzielić życiowych uwag. Starsi księża-emeryci wiele również czasu poświęcają systematycznemu kierownictwu duchownemu.

si $R C R, 61$. 
Księża profesorzy-emeryci oddają się pracy pisarskiej w najszerszym tego słowa znaczeniu, tj. zarówno pracy naukowej, jak i pracy kronikarsko-wspomnieniowej. W ten sposób oddają nieocenione usługi dziejom danej parafii czy diecezji, czy też historii jakiegoś okresu w Kościele polskim.

$\mathrm{Na}$ ogół już nie uczą religii, gdyż na emeryturę idą o wiele później aniżeli księża w USA. To samo dotyczy nauk konwertytów, których u nas zresztą nie ma tylu co w Ameryce Północnej, gdzie katolików jest tylko 1/4 ogółu ludności i stąd przypadki konwersji są częste.

- Przygotowanie do przejścia na emeryturę (USA-PRL)

Zarówno w USA jak i w Polsce odpowiednie czynniki urzędowe zdają sobie sprawę $\mathrm{z}$ ważności pewnych aktów przygotowujących starszych kapłanów do przejścia na emeryturę. W tym miejscu oba badane środowiska potraktujemy łącznie.

Przede wszystkim uwzględnia się zasadę jak najdalej idącej wolności w podejmowaniu decyzji pójścia na emeryturę przez starszego księdza, zwłaszcza w przypadku opcjonalnej formy. Gdy chodzi o formę obowiązkowego przejścia na emeryturę (mandatory retirement), należy podkreŚlić bardzo ważne momenty psychologiczne przygotowujące kandydata do uczynienia tego kroku. Przytoczymy istniejące w tym względzie zasady.

1. Ze strony władzy duchownej:
a) wspólna narada biskupa $\mathrm{z}$ kandydatem
b) uwzględnienie życzeń kandydata
c) udzielenie duchowego wsparcia

2. Ze strony kandydata-emeryta:
a) trzeźwa ocena własnych możliwości
b) dłuższe nastawianie się na fakt przejścia na emeryturę lub do innej funkcji kapłańskiej
c) kształtowanie w sobie właściwej postawy du- chowej

ad 1) Z kandydatem-emerytem biskup przede wszystkim aranżuje osobiste spotkanie i szczerą rozmowę. Najlepiej udaje się to przy jakiejś oficjalnej okazji, np. przy złożeniu życzeń imieninowych, przy okazyjnym odwiedzeniu kandydata, przy zaproszeniu z jego strony. W rozmowie tej znajdą się takie pytania, jak:

- Jakie jest zdrowie kandydata?

- Kiedy chciałby pójść na emeryturę?

- Gdzie chciałby zamieszkać? 
- Na jaką pomoc pieniężną liczy?

- Jak wyobraża sobie przyszłą aktywność kapłańską?

Kandydat-emeryt oczekuje duchowego wsparcia ze strony swego biskupa.

ad 2) Kandydat-emeryt musi także sam „popracować nad sobą”, aby się duchowo przygotować do faktu przejścia na emeryturę i do życia $\mathrm{w}$ warunkach emerytalnych. Winien praktykować autoanalizę i heteroanalizę, odnośnie do swoich sił i pomocy otoczenia. Dłuższe psychiczne oswajanie się z myślą o konieczności zrezygnowania z pełnoetatowej pracy kapłańskiej pozwoli mu uniknąć zaciągania rany psychicznej (psychic trauma), gdy już dojdzie do faktu wycofania się z dotychczasowego rytmu pracy (trauma transition). Pozwoli to również uniknąć traumatycznego lęku przed starością czy ewentualną utratą szacunku u innych $\mathrm{z}$ tego powodu, że się już nie piastuje urzędu.

Mierzyć bowiem zamiary według sił nie jest słabością, ale mądrością, gdyż „po tym mądrego poznać w tłumie, że to tylko robi, co robić umie" (A. Mickiewicz). Tak w Ameryce, jak i w Polsce...

Oczywiście, to co tutaj napisaliśmy jest zaledwie ramowym zarysem aktów przygotowawczych do przejścia na emeryturę i życie kapłana-emeryta w nowych warunkach i to zarówno w środowisku amerykańskim jak i polskim.

- Opieka pastoralna nad księżmi-emerytami (USA-PRL)

Opis warunków opieki pastoralnej nad księżmi-emerytami oraz nad ich dalszym rozwojem duchowym ze strony władzy kościelnej, tak w USA, jak i w PRL, chcemy potraktować łącznie, ponieważ mają one wiele punktów stycznych i podobnych.

Ksiądz na emeryturze pragnie mieć świadomość, że się o nim nadal pamięta, że się go nadal ceni (potrzeba akceptacji), że się go jeszcze potrzebuje do pełnienia niektórych posług kapłańskich. Przede wszystkim jednak, starszy ksiądz chce mieć świadomość, że się liczy jego wiek i doświadczenie. Szczególnie podnosi go na duchu fakt zaciągania jego opinii, rady itp. Toteż kurie biskupie wysyłają księżom-emerytom aktualne biuletyny duszpasterskie, listy biskupie, życzenia świąteczne czy imieninowe, prosi się ich do udziału w dyskusji.

Zwykle też nagradza się ich honorowymi nominacjami, zarówno diecezjalnymi, jak i papieskimi oraz honorowymi tyłułami. Ta wieloraka troska o sprawy materialne i duchowe wraz z potrzebami psychicznymi u księdza-emeryta nosi nazwę opieki pastoralnej.

W USA istnieje osobny referat przy kurii biskupiej dla spraw księży-emerytów. $\mathrm{Na}$ jego czele stoi wyznaczony przez ordynariusza starszy kapłan, w stopniu urzędnika kurialnego. Do niego mogą się zwracać 
księża-emeryci z każdym problemem. On - w razie potrzeby - interweniuje, pomaga i jest zawsze do dyspozycji księży-emerytów. Jego autorytet, osobista kultura i dobroć odgrywają wielką rolę.

Pod tym względem nie ma zasadniczej różnicy między zwyczajami w USA a tymi, które również są praktykowane w Polsce. Księża-emeryci są u nas bardzo cenieni przez biskupa ordynariusza, który nie tylko o nich ogólnie pamięta, ale też ich osobiście odwiedza, radzi się ich, nagradza odznaczeniami, zleca im honorowe przewodnictwo w zabraniach itp.

\section{- Dalszy rozwój duchowy księży-emerytów (USA-PRL)}

Zgodnie z najnowszymi postępami badań psychologicznych, starzenie się nie jest jedynie procesem kończenia się życia (end-of-life process), lecz jest kontynuacją rozwoju i dojrzewania duchowego (life-long process). Po przejściu na emeryturę kapłan dalej się wewnętrznie rozwija, duchowo dojrzewa i bogaci swoje wnętrze. Emerytura nie jest stagnacją, lecz rozbudową życia duchowego. Oczywiście, nigdy życie kapłana nie jest jednostronną aktywnością zewnętrzną. Nigdy nie bywa ono ekspozycją i ewolucją jedynie osobistych talentów. Życie kapłana $w$ jego nurcie wewnętrznym płynie równolegle do aktywności zewnętrznej. Na emeryturze dokonuje się dalsze upodobnienie do Chrystusa, swoiste dopełnienie (Fullness in Christ - jak to określa Komisja Biskupia dla życia i posługiwania kapłanów w USA). Rezygnacja $\mathrm{z}$ odpowiedzialności administracyjnej $\mathrm{w}$ parafii nie jest obniżeniem znaczenia kapłana, lecz przeciwnie - dalszym stopniem w kierunku identyfikacji z Chrystusem. Jest ono nieocenionym wkładem w życie dla dobra diecezji i Kościoła jako całości. Można nawet mówić o pewnej specyficznej dymensji życia duchownego kapłana-emeryta w oparciu o nowe sprzyjające temu warunki.

Niektóre $\mathrm{z}$ tych warunków warto tutaj wyliczyć: atmosfera modlitwy (więcej czasu, więcej spokoju); możliwość stałego dziękczynienia za kapłaństwo i złączone $\mathrm{z}$ nim dary przez liczne Msze św. dziękczynne; refleksja i medytacja, jako znakomite środki pomocnicze w okresie emerytury $\mathrm{w}$ odnoszeniu swego życia do Boga, w ofiarowaniu całego posługiwania kapłańskiego i zebranego w życiu doświadczenia Bogu „od którego pochodzą święte pragnienia, prawe zamiary i czyny cnotliwe" (por. modlitwa po litanii do Wszystkich Swiętych). Również uczestnictwo $\mathrm{w}$ koncelebrze $\mathrm{z}$ młodszymi wiekiem konfratrami stanowi nie tylko okazję do przeżywania jedności w kapłaństwie, ale także środek przeciw duchowej izolacji, zagrażającej czasem emerytowi.

Prawdziwe życie duchowe nie obywa się nigdy bez cierpień. Truizmem jest, że ksiądz-emeryt musi się pogodzić z pewnymi ogranicze- 
niami (dieta) $\mathrm{w}$ zakresie wydolności $\mathrm{w}$ pracy. Wymaga to również pewnej ascezy. Ale też kapłan w starszym wieku posiada dużo więcej sprawności i duchowej siły do pewnych ofiar z przyjemności, jakie daje życie „na pełnych obrotach” i z widokiem sukcesów swej pracy. Musi on zadowolić się skutkami dla oka niewidocznymi. Na to jest on $\mathrm{w}$ wieku emerytalnym bardziej przygotowany niż w poprzednim okresie.

\section{ZAGADNIENIE ADAPTACJI DO ŻYCIA NA EMERYTURZE}

Wspomnieliśmy już powyżej (s. 343), że przejście na emeryturę jest nie tylko problemem materialno-finansowym. W stopniu o wiele większym jest ono problemem psychologiczno-adaptacyjnym. Jego rozwiązywanie zaczyna się, jak to zaznaczyliśmy (s. 349-350), na długo przed formalnym przejściem na emeryturę, czyli w okresie przygotowawczym. Można nawet powiedzieć, że udany program przygotowania się kandydata do warunków na emeryturze w dużym stopniu będzie decydował o właściwym przebiegu adaptacji po przejściu na emeryturę, albowiem już wstępna i ogólna analiza problemu adaptacji do emerytury ukazuje nam podwójny aspekt tego zagadnienia: prospektywny i retrospektywny.

Pierwszy dotyczy pytania, jakie są trudności i sposoby ich rozwiązania przed przejściem na emeryturę. Drugi dotyczy problemów, powstających po przejściu na emeryturę.

Istotną rolę pełni na pewno przygotowanie się do przejścia na emeryturę. Czy jednak wszystko da się naprzód przewidzieć? Rzeczywistość jest zawsze trochę inna aniżeli jej prawdopodobne wyobrażenie. Doświadczenie jest znakomitym uzupełnieniem poznania, a właśnie doświadczenie może wyłonić zupełnie nowe problemy, zarówno o charakterze subiektywnym, jak i obiektywnym. Co innego bowiem jest znać poprzez wyobrażenie, jaka może być rzeczywistość, a co innego osobiście jej doświadczać. Własne doświadczenie jest zawsze jedyne i nieporównywalne. Od strony obiektywnej rzeczywistość może wyłonić coś nieprzewidzianego. Może zaskoczyć sytuacją nową, której się obsolutnie nie dało naprzód przewidzieć (np. pewne czynniki przypadkowe, wypadki losowe, nowe idee, układy stosunków międzyludzkich itp.). Warunki życia z początku bardzo dobre mogą się zmienić na gorsze i to zarówno ze strony danej jednostki, jak zwłaszcza ze strony układów od niej niezależnych. Jest również prawdą, że poznanie i doznanie wzajemnie się uzupełniają. Człowiek nie zna życia dopóki nie dozna w nim różnych przeciwności życiowych.

O ile jednak ze starością żyje się przez dłuższy czas, to przejście na emeryturę trwa krótko. Jest to chwila nowa i nieznana, którą człowiek przeżywa w życiu po raz pierwszy. Słusznie zauważono, że „, nie tyle sama 
starość ile przejście (p.m.) do okresu starości i emerytury stwarza problemy przystosowania",37.

Zagadnienie adaptacji starszych kapłanów do przejścia na emeryturę i do życia na emeryturze stanowi główny problem tej pracy. Jego rozwiązanie będzie rezultatem naszych badań metodą eksperyment a ln ą.

W tym miejscu posłużymy się metodą o $\mathrm{p}$ is o w ą (descriptive method), przy pomocy której naświetlimy samo zjawisko adaptacji.

Co rozumiemy przez adaptację? Pojęciu adaptacji odpowiada angielskie słowo ,adjustment”, czyli przystosowanie. Adaptacja jako przystosowanie oznacza ",harmonię między jednostką a jej fizycznym lub społecznym otoczeniem" "s8. Adaptacja może być pojęta, bądź jako stan, bądź jako proces. Adaptacja jako stan oznacza całkowite zaspokojennie potrzeb jednostki i wymagań otoczenia. Adaptacja jako proces oznacza to wszystko, co prowadzi do osiągnięcia wspomnianej harmonii.

Oczywiście, adaptacja jako stan calkowitej harmonii między jednostką a jej otoczeniem funguje raczej tylko jako termin idealny. W praktyce bowiem taka calkowita harmonia rzadko kiedy bywa osiągana. Można zatem mówić raczej o względnej harmonii.

Mówimy o harmonii między potrzebami jednostki i wymaganiami jej otoczenia. Ma to szczególne zastosowanie, gdy chodzi o adaptację do otoczenia społecznego, czyli do innych osób. Trudno bowiem nazwać harmonią jednostronne tylko zadowolenie jednostki, które ona osiąga tyranizowaniem swego otoczenia. W procesie właściwej adaptacji musi dojść do obopólnego porozumienia. I taki stan mamy na myśli, gdy mówimy o harmonii.

Natomiast, gdy mówimy o procesie adaptacji to mamy zwykle na myśli różne działania przystosowawcze ze strony danej jednostki, jej problemy $i$ wysiłki $w$ tym kierunku. Jednym słowem, patrzymy na zagadnienie adaptacji $\mathrm{z}$ punktu widzenia jednostki będącej podmiotem procesu adaptowania się.

Ta względna harmonia urzeczywistnia się na drodze dynamicznego procesu, tj. wśród ciągle zmieniających się zapotrzebowań, zarówno jednostki, jak i jej otoczenia, toteż jednostka musi stale praktykować wysiłki przystosowawcze w zależności od fluktuacji warunków, w których żje.

Za względną harmonię we współżyciu jednostki z jej otoczeniem przyjęło się uważać b r ak k onfliktó w ${ }^{39}$. Chodzi tutaj, oczywiście, nie

37 Bromley, dz. cyt., 92 .

3 H. J. Eysenck, W. Arnold, E. Meili, Encyclopedia of Psychology, New York 1979, 25.

39 W. D. Fröhlich, mówiąc o adaptacji społecznej wyjaśnia, że polega 23 - Analecta Cracoviensia 
o brak jakichkolwiek konflików $\mathrm{z}$ otoczeniem, co byłoby rzeczą nierealną, ale o brak poważnych, długotrwałych nieporozumień, z którymi jednostka nie potrafi sobie poradzić i na które reaguje jakąś formą depresji.

Warto dodać, że mówiąc o adaptacji jednostki do otoczenia, mamy na myśli zarówno jej sferę biologiczną, jak i psychiczną. Między jedną i drugą istnieje stosunek wzajemnej zależności.

Adaptacja różni się od asymilacji, która polega na przyjmowaniu, tj. wchłanianiu cennych elementów życiowych od otoczenia. Można nawet powiedzieć, że o ile adaptacja jest aktywnością psychiczną na linii od jednostki $\mathrm{ku}$ jej otoczeniu, to asymilacja jest aktywnością od jej otoczenia ku niej samej. W procesie adaptacji jednostka pełni rolę zależną od otoczenia, tzn. musi się do niego dostosować. W procesie asymilacji otoczenie występuje w roli „obdarzającego". W adaptacji jednostka służy otoczeniu, w asymilacji otoczenie służy jednostce.

Przenosząc to na teren naszych rozważań tematycznych powiemy, że adaptacja jest dawaniem, asymilacja natomiast jest braniem. Albo jeszcze inaczej, adaptacja jest rezygnowaniem $z$ własnych potrzeb na korzyść potrzeb drugich asób. Asymilacja zaś jest bogaceniem się $w$ te dobra, które otoczenie ma do zaofiarowania. Sądzimy, że w tym sensie, zarówno bogacenie drugich poprzez przekazywanie im swych oryginalnych i własnych dóbr osobowościowych (adaptacja), jak i bogacenie siebie takimiż dobrami pochodzącymi od innych osób (asymilacja), składają się w jednej i tej samej jednostce na różnorodne as pekty dy namiczności procesu przystosowania, czyli adaptacji.

Rozważając $w$ dalszym ciągu zjawisko adaptacji na podstawie potocznego tylko obserwowania życia starszych osób (metoda opisowa), wydaje się, że można stwierdzić, iż w każdym właściwym procesie adaptacji występują dwie zasady:

1) Przeświadczenie, że się jest nadal potrzebnym i użytecznym dla drugich, mimo że się jest już emerytem.

2) Poczucie ciągłości i identyczności, mimo zaistniałych zmian fizjologicznych, psychicznych i społecznych u tej osoby.

Spróbujmy rozważyć znaczenie obu momentów psychologicznych.

ad 1) Jednym z najbardziej przykrych stanów wewnętrznych każdego człowieka może stać się świadomość własnej niepotrzebności, że już nie można czynić drugim dobrze $\mathrm{w}$ takim stopniu, $\mathrm{w}$ jakim się to czyniło w wieku młodszym. Bolesną rzeczą jest skonstatowanie, że inni

ona na takim współżyciu $\mathrm{z}$ innymi, w którym nie ma konfliktów: ,a state of social equilibrium in the sense of experiencing no conflict (p.m.) with the milieu".

R. Hanni stwierdza, że aby można było mówić o dobrej adaptacji, wystarczy, że osiagga się względny jej stopień (relative adjustment), por. Eys enck i in., dz. cyt., 25. 
mogą się zupełnie dobrze obywać bez naszej pomocy. Powstaje wówczas poczucie jakiejś pustki, jakiegoś niedosytu. Tymczasem, natura abhorret a vacuo - natura nie znosi próżni. Albowiem, gdy się jest poszukiwanym cenionym, gdy zawsze ktoś na nas czeka, wówczas czujemy radość życia i działania. Znajdujemy również siłę do pracy i do poświęcenia. Słusznie powiedział Pierre Janet, iż „czyn rodzi siłę”, tzn. wewnętrzna energetyka człowieka karmi się aktywnością, osiągnięciami, przygodą (por. law of effect) ${ }^{40}$. Gdy tego wszystkiego mniej, a zwłaszcza, gdy jest się zmuszonym do pracy dorywczej i nieobowiązkowej tylko - jak w wypadku księdza emeryta - wówczas może zagrażać jakaś apatia, zgadzanie się na bezruch oraz pokusa zazdrości na widok radosnego działania innych ludzi.

ad 2) Wspomnieliśmy już, że adaptacja jest m.in. brakiem poważnych konfliktów. Dotyczy to przede wszystkim stosunków z otoczeniem, wśród którego się stale przebywa. Ale istnieje też możliwość powstania konfliktu wewnątrz samej jednostki, zmuszonej do wycofania się $\mathrm{z}$ normalnego trybu życia i pracy $\mathrm{w}$ związku $\mathrm{z}$ przejściem na emeryturę. Nagle bowiem urywają się dotychczasowe związki uczuciowe, kontakty osobowe itp. Zmienia się nawet porządek dnia oraz rytm wyznaczany przez obowiązkową pracę na dany dzień, miejsce czy godzinę itp. Kończą się dawne zajęcia, nowe zaś są albo mniej obowiązkowe, albo w ogóle ich jeszcze nie ma. W tej sytuacji łatwo o pojawienie się poczucia braku ciągłości, co zawsze łączy się z wewnętrznym zamieszaniem i niepokojem.

Ważnym elementem zdrowia psychicznego osoby ludzkiej jest poczucie swojej identyczności. Dzięki niej człowiek jest sobą, wie na co go stać oraz na jaki szacunek ma prawo liczyć od swojego otoczenia. $\mathrm{Z}$ tej racji kim on jest, co potrafi, czego dokonuje na oczach innych ludzi, człowiek bywa przez drugich rozpoznawany i przez nich szanowany. $\mathrm{Na}$ emeryturze schodzi on nieco w cien. Inni mniej się już z nim liczą, ponieważ mniej zarabia jako emeryt i nie ma już władzy. Dokuczliwe poczucie mniejszej wartości wyrasta zwykle z braku poczucia własnej identyczności.

Toteż proces adaptacji musi rozwiązać powyższe dwa problemy emerytalne. Musi stworzyć warunki, które pozwoliłyby księdzu-emerytowi na zachowanie przeświadczenia, że mimo wycofania się z dotychczas zajmowanego stanowiska lub jakiejś jego części, jest on nadal bardzo cenionym ze względu na świadczoną pomoc duszpasterską, chociaż już $w$ innym miejscu lub w innym charakterze.

Poza tym adaptacja musi także zaspokoić słuszną potrzebę ciągłości

40 j.w., 1108. 
i identyczności u księdza-emeryta. W każdym razie, musi mu ona dopomóc zachować poczucie własnej wartości.

Zanim sprawdzimy, jakie są przyczyny różnego przeżywania lat emerytalnych oraz typy postaw księży-emerytów wobec swej emerytury, spróbujemy jeszcze pokazać obraz emeryta przystosowanego i nieprzystosowanego do życia w nowych warunkach emerytalnych.

O dobrym przystosowaniu świadczy zawsze fakt, że emeryt jest szczęśliwy ze swojego życia i warunków, w jakich mu ono upływa, gdy ma zaufanie do ludzi i cieszy się także ich przyjaźnią i zaufaniem, jest towarzyski i według swojej możliwości aktywny, ma szacunek dla siebie samego, jest wolny od chorobliwych stanów emocjonalnych ${ }^{41}$.

Słusznie podkreśla D. B. Bromley, że tzw. dobre samopoczucie i poprawne stosunki z innymi ludźmi są lepszymi wskaźnikami przystosowania niż „umiejętność wypełniania swych ról społecznych", względnie „zdolność do pracy i sytuacja materialna" ${ }^{42}$.

Za znak złego przystosowania uważa się takie objawy, jak: postawa wrogości czy żalu do innych, chorobliwe lęki lub poczucie winy, stany przedłużającej się depresji i apatii, brak radości życia, obawa przed ludźmi, podejrzliwość w stosunku do innych, traumatyczne odczuwanie własnej niższości, izolowanie się od innych, niesłuszne przekonanie o braku kompetencji u siebie, skłonność do kłótni itp.

Zarówno dobre, jak i złe przystosowanie, jak sądzą psychologowie, zależy przede wszystkim od wypracowania w sobie właściwego stosunku do otoczenia. Wrodzony optymizm może w przystosowaniu dopomóc, natomiast pesymizm wrodzony (względnie traumatyczny, a więc nabyty) może ten proces utrudnić. Podobnie pewne warunki zewnętrzne mogą sprzyjać przystosowaniu lub pogłębić nieprzystosowanie. Ostatecznie jednak, jednostka musi sama wypracować $\mathrm{w}$ sobie postawę przystosowania, by nie dopuścić do ukształtowania się postawy negatywnej.

Znamienne jest to, co $\mathrm{w}$ trakcie swoich doświadczeń zauważyli niektórzy psychologowie, że „optimum przystosowania osiągają ludzie, których warunki i zachowanie się ulegały ciąg 1 y m z mianom (przekształceniom) w okresie całego życi a" ${ }^{43}$. Wynikałoby z tego, że pewna stałość czy niezmienność warunków zewnętrznych powoduje swoistą sztywność postaw. Jedno i drugie wyraża się ostatecznie nieprzystosowaniem.

Proces przystosowania bowiem, czyli adaptacji, zakłada ex definitione

41 Por. R. J. Havighurst, Successful aging, in: Process of Aging. Social and Psychological Perspectives, New York, t. I, 1963, 299-320.

42 B r o mle y, dz. cyt., $143-144$.

43 T e ṅ̇e, dz. cyt., 144. 
dynamiczność i elastyczność reagowania jednostki, zarówno w sferze intelektualnej, jak i uczuciowej i wolicjonalnej. Przy ich pomocy człowiek potrafi łatwiej radzić sobie z wszelkimi nowymi problemami, które stwarza współżycie $\mathrm{z}$ innymi osobami i w nowych warunkach socjalno-bytowych. Ten aspekt omówiony w innym studium.

\section{THE PSYCHOLOGICAL ASPECTS OF THE RETIREMENT OF ELDERLY PRIESTS}

Sum mary

This is the leading article of a large study, entitled The Process of Adjustment to Retirement in Elderly Priests in which individual reactions to the psychological fact of retirement were examined. Our aim was the discovery of the mechanisms of psychological adjustment to retired life. The examined gnoups consisted of elderly priests, both those who have already retired and those who are preparing for retirement. Retirement may be prepared for accepted and experienced differently by different priests, as a result of individual efforts to adjustment. We shoud, however, distinguish between adjustment as a process and adjustment as an effect, i.e. the state resulting from that process. Moreover there seems to exist a certain ability to adjust i.e. a certain efficiency in organizing the level of adjustment. In adjustment as a process there are at least two kinds of psychological reaction of adjustment to the existing conditions of retired life. The effect both of preparation for and adjustment to retirement may vary, i.e. it can be greater or less depending on conditions such as: the life history of the given man, the atmosphere of his family etc. The most important factor in the process in the individual's self-image, which can have a favourable or a detrimental effect; however, it is always connected with the degree of open-mindness with which he goes through the adjustment process.

In the present study we tried to examine the interdependence of the existing self-image and of the level of adjustment to the conditions of retired life, bearing in mind the following aspects: the diagnostic aspect, the practical aspect, the therapeutical aspect, i.e. atempts to explain the psychological phenomenon. From our study we were able to draw practical conclusions concerning special psychological therapy to be recommended where problems concerning adjustment to retired life in the priesthood occur. The three main subjects dealt with in the article were the psychophysiology of ageing, the retirement of elderly priests, and their adjustment to retired life. 